\title{
Productivity Enhancement: Implementing and Analyzing Clustering Method in Manufacturing of Gearbox Housing
}

\author{
Vinit Boora* and Sandeep Singhal \\ Department of Mechanical Engineering, National Institute of Technology, Kurukshetra, Haryana, India
}

Received 20 April 2018, Accepted 22 June 2018, Available online 10 July 2018, Vol.8, No.4 (July/Aug 2018)

\begin{abstract}
Productivity is the index of performance with which assets, each human and material, are converted into beneficial services and items. The vital relevance of the present work was to research the elements involved in the development of productiveness in all its types which include capital, material, labor, machine, and general productivity at the enterprise. This turned into received by means of reducing the manufacturing cost of the component through reduction of its cycle time and increasing the month-to-month production implementing clustering method. The experimentation found out that the usage of proposed methods and improved tooling has increased the monthly production rate by $20 \%$ by dint of reduced cycle time. Rejection rate, i.e., defected components has decreased up to $2 \%$. A reduction of $9.7 \%$ in part manufacturing cost was recorded. Tooling cost has decreased by way of greater than 10\%. Up to 50\% saving in inspection cost was reported on account of closer dimensional tolerances and superior finish achieved on manufactured parts. An improvement of 5.25\% was claimed in total productivity.
\end{abstract}

Keywords-inventory; labor productivity; material productivity; cycle time; manufacturing cost; total productivity; clustering; statistical analysis

\section{Introduction}

'Productivity' has come to be a flexible word as by using and huge all and sundry talks about it. The meaning of "productiveness" is unique for individual humans. Therefore, it changes from efficiency to effectiveness. Productivity is an indicator of the efficacy and ability by which an enterprise or an agency converts its available assets into completed goods or offerings, i.e., required outputs. Productivity can be stronger by producing greater output with the same enter or by means of producing the identical output with lesser inputs. Productivity may be defined as human efforts to supply an increasing number with much fewer contributions of resources because of which the production advantages are dispensed among the most variety of people. The manner of productivity is stability among the whole elements of production to give maximum output with the smallest attempt.

Author conceded that cost drawback, scheduling, layout strategies, quality control and making ready workforce are essential purposes continually sensed over a long time as stimulating productiveness (Arditi and Mochtar, 2000). The super charge of turnover might be contributive for the enhancement of the industrial productiveness if resources are interchanged

*Corresponding author's ORCID ID: 0000-0002-9411-3684 DOI: https://doi.org/10.14741/ijcet/v.8.4.6 from extra skilled manufacturer to much less efficient one (Aw et al., 2001). The ratio of output indicator to the input index is the measuring device for productivity alteration (Balk, 2005). Developing green place of job for personnel, rendering them responsible and supported at work by turning in more obligation to them, ensuring more competency, better satisfied with their jobs, greater dedicated to employers, probably extra effective, in all likelihood to growth retention and displaying better intellectual health, ensuing in better productivity (Bond and Galinsky, 2006).

Automation in procedure proved to be more active, therefore yielding the productivity values (Bryson et al., 2005). Productivity measurement commonly imagined being the ratio of produced outputs to resources consumed (Card, 2006). The paper formulates a replacement framework which enforces incentive modulation to allocate offers to universities to increase their productiveness (Carrington et al., 2016). The author stated that after the pre and postreforms, a long time, hardly any effort to verify the sources to enhance stellar business performance made. The study estimated the total factor productivity increase of the producing industries of various states of India (Dash et al., 2010). Technical innovation viz. data sources, technology procurement, technological cooperation, governmental assistance, patents, affect productivity development (Doo and Sohn, 2008). More productivity means accomplishing greater technology 
with less effort and cost (Faulk et al., 2004). Productiveness is a consistent adaptation of social and economic existence to changing conditions. It's far the persistent effort to use new methods and techniques. As a coverage attitude, it's now regular to recognize which factors underlie the distinction in productiveness throughout firms and that is related to higher productiveness (Fernandez, 2008). Opposed the findings of several precedings research; a cutting-edge studies approximately productiveness trends in Indian manufacturing via unel (2003) settled that Total Factor Productivity increase multiplied after 1991economic reforms (Goldar, 2004). Outsourcing of substances for flora with low export intensities notably accelerated the productivity (Gorg and Hanley, 2005).

The author concluded that small and medium enterprises (SMEs) had performed an essential function in economies of entire most critical industrial societies regarding each gross domestic product in addition to employment levels continuously. Inside the latest past, maximum of the brand new manufacturing ideas and technology carried out on a massive scale in manufacturing industries for productiveness enhancement (Gunasekaran and Cecille, 1998). The credit unavailability and excessive inflation combination stimulated distortion and besides decreased the productivity growth (Gupta, 2010). The automobile industry is undergoing severe competition and striving to plan strategies to lessen manufacturing cost as well as waste will be falling. Enforcing lean production method in-process stock declined to boost up the manufacturing system, consequently applying the sources entirely in the shape of the machines and staff, the productiveness was raised (Hemanand and Amuthuselvan, 2012). Maximum of the papers have stressed that misallocation of inputs throughout the firms can decrease aggregate total factor productivity in a nation. Useful resource reallocation can boom aggregate total factor productivity (Hsieh and Klenow, 2007). The findings suggest that the overall factor productivity growth of Indian industry often for a formal sector has suffered from SBR (Kathuria et al., 2010). It's been found that in-process stock reduction stimulated benefit in productivity (Lieberman and Demeester, 2002). The proof indicates that a business enterprise's involvement in R\&D activities reports for big productivity profits (Medda and Piga, 2014). An additional sustainable and excessive productivity manufacturing system may be evolved to decide the productiveness level of the enterprise (Mohaddes and Mazhari, 2008).

It's miles concluded that converting ownership by converting a massive quantity of firms to stockmaintaining companies positively make contributions to increase in aggregate productivity (Motohashi and Yuan, 2009).

An econometric search of determinants of the total factor productivity increase interprets that literacy, proprietorship; availability of infrastructure and farm growth drastically affects total factor productivity increase inside the place (Natarajan and Duraisamy,
2008). The average productiveness of India's production enterprises has been improved through a unilateral reduction in tariffs for final goods (Nataraj, 2009). With reduced lead time presumed for producing the products, productiveness development stimulated through spotting different forms of waste cached up consolidating numerous manufacturing steps and picking the vital one (Saleeshya and Bhadran 2015).Productiveness enhanced through decreasing the cycle time and statistically controlling the method (Sheth and Sisodia, 2002). Paper imparts a brand new insight into factors related to the betterment of partial productivity in distinctive aspects along with material, machine, labor, and capital productivity (Singh and Singhal, 2018). Allocation and use of recognized sources carried out a widespread function inside the enterprise for the enhancement of quality and productiveness (Sivakumar and Saravanan, 2011). The predominant finding emerged from the observation is wages that is the most critical number one determinant of labor productiveness. Furthermore, the relationship between ICT and productiveness hooked up indirectly (Skorupinska and Torrent-Sellens, 2017). Focusing interest on production productivity or the aggregate production efficiency as the vital indicator of competitive capability and strength, usual overall performance could be enhanced (Sohail, 2006). Supplied the outcomes of a look at undertaken in inspecting the utility and impact of manufacturing productivity enhancement strategies within automobile parts suppliers. The survey result for 161 automobile suppliers was offered. the paper emphasizes the adoption of non-stop development tools and comprehensive methodologies (Trimble et al., 2013). The paper exhibits, stepped forward fixturing increased the productiveness by improving floor roughness properties and vitally decreasing the processing time (Walia et al., 2009). Productivity progressed using single-piece flow approach. Plenty of data have been taken and prove the boom through making sure single piece flow technique (Yazid, 2007).

\section{Problem formulation and Methodology}

Problem forming describes a quick background for the manufacturing of the automotive components in business enterprise and importance of keeping high production along with better quality. Also, it pertains to our specific study and ends in our problem definition. As to begin formulating a particular problem; the first portion of the studies is to manage a pre-investigation with the intention to apprehend the manufacturing process in a better manner and to locate viable components influencing the productivity performance of organization or company. Performing the numerous operations on specific machines making use of traditional strategies need significantly more time, ample space, labor cost, material managing cost, shipment price and as a result overall manufacturing cost is the outcome of all of the above-discussed elements and productivity is a subject term on the 
above-detailed aspects. The to-days manufacturing requires to attain high productiveness and consequently to lessen unit production cost which necessitates some advanced production methods or techniques to be worked out for producing the specified parts. Assets required to be utilized successfully and job holding accessories to be green making sure quick loading/unloading to hurry up production operation. The existing work become accomplished in a tractor components manufacturing corporation near Ambala metropolis of Haryana (India), in which the management of the organization favored that with the present sources; productiveness be extended with the aid of decreasing the lead time of complicated shaped parts, boom the manufacturing of such critical component, i.e., gearbox housing and also month-to-month rejection be reduced through clustering various operations and carrying out most clustered activities on a single computerized numerically controlled machine facilitated with required controls.

Methodological steps proven in the underlying flowchart are vital to find out the above-constituted problem and to examine efficient utilization of sources available and perfection of production in addition to productivity.

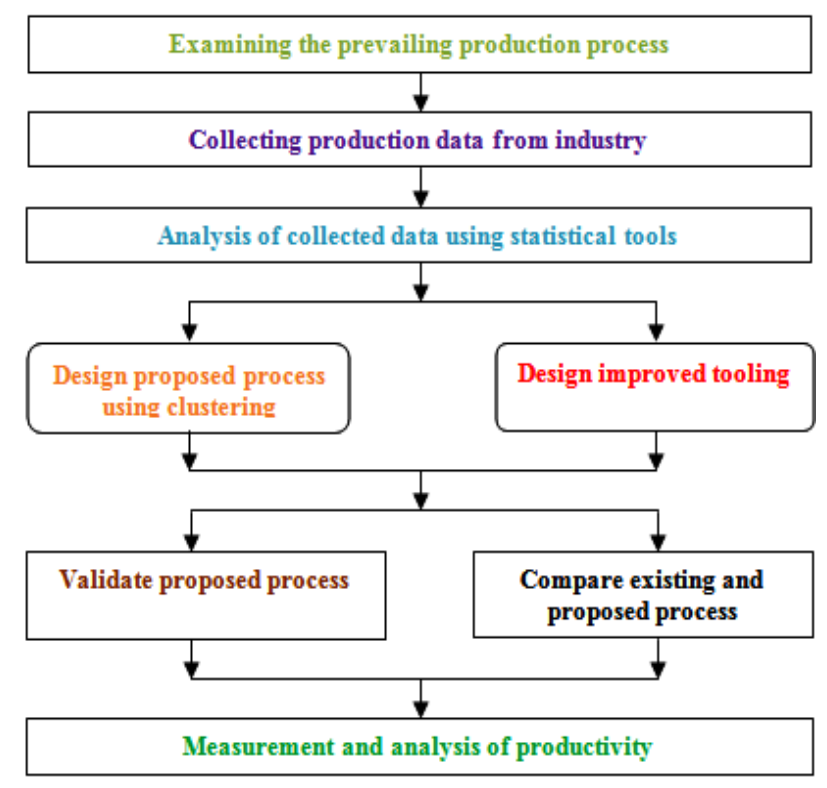

Flow Chart for Methodology adopted

\section{Examining Existing Methods}

For prevailing production methods, numerous parts produced by the enterprise, machinery, and types of equipment established at the plant need to be examined. An essential part of the list of automobile parts manufactured in the company, namely gearbox housing, is shown in Fig 1.

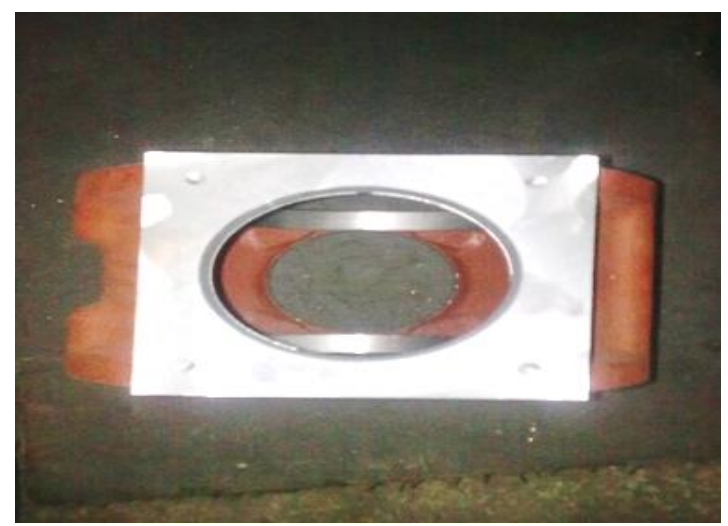

Fig 1 Gearbox housing
The operation time chart for the vital component socalled gearbox housing is shown in Table 1.

Description of present operations with their sequential order, the different machine used, and time spent on each of the machines to perform the essential operation, component production cost, helper cost and in-house material shipping and handling cost in manufacturing gearbox housing shown in table 1 . Total 07 operations are performed to produce the above mentioned component.

Following assumption are undertaken to prepare the existing operation time chart for gearbox housing.

- Machine hourly rate for various machines shown in table 1 involves machine purchasing cost, interest, depreciation, incurred wages, power consumption, tooling and miscellaneous overheads cost.

- The component manufacturing cost includes machining cost, helper cost and in-house material handling and shipping cost.

- Machining cost calculated from machine hourly rate multiplied by time consumed on the connected machine.

- Helper rate was taken as ₹16 an hour. 
Table 1 Gearbox housing existing operation time chart

\begin{tabular}{|c|c|c|c|c|c|c|c|}
\hline Op. No. & Operations description & $\begin{array}{c}\text { Connected } \\
\text { Machine }\end{array}$ & $\begin{array}{l}\text { Avg. Cycle } \\
\text { Time }\end{array}$ & $\begin{array}{l}\text { Machining } \\
\text { Rate/Hour }\end{array}$ & $\begin{array}{c}\text { Component } \\
\text { of Cost }\end{array}$ & $\begin{array}{c}\text { Material } \\
\text { shipping Cost }\end{array}$ & $\begin{array}{c}\text { Helper } \\
\text { Cost }\end{array}$ \\
\hline 1 & Rough And Finish Machining Bore $\emptyset 141$ & $\begin{array}{l}\text { Centre } \\
\text { Lathe }\end{array}$ & $15 \mathrm{~min}$ & $80 /-$ & 20.00 & 1.00 & 4.00 \\
\hline 2 & Finish Machine Bore $\emptyset 72 \mathrm{H}^{8}$ And Bore $\emptyset 90 \mathrm{H}^{8}$ & vmc-500 & $15 \mathrm{~min}$ & $300 /-$ & 75.00 & 0.50 & 4.00 \\
\hline 3 & $\begin{array}{c}\text { Finish Groove Dia. } \varnothing 75 \text { And } \varnothing 95.5 \text {,Central Dia.70 } \pm 0.2 \text { Bore } \\
\text { To Bore Finish }\end{array}$ & vmc-500 & $15 \mathrm{~min}$ & $300 /-$ & 75.00 & -- & 4.00 \\
\hline 4 & Top Dimension 190 Finish Drill $\emptyset 12,4$ No off Holes & VMC-500 & $10 \mathrm{~min}$ & $300 /-$ & 50.00 & -- & 2.67 \\
\hline 5 & $\begin{array}{c}\text { Opening Of Drilled Hole Ø8.5 Eight Holes, Tapping M10, } 4 \\
\text { Holes }\end{array}$ & $\begin{array}{l}\text { Conv. Centre } \\
\text { Lathe }\end{array}$ & $5 \mathrm{~min}$ & $100 /-$ & 8.33 & 1.00 & 1.33 \\
\hline 6 & $\begin{array}{l}\text { Drill Ø6.8 One Hole, Tapping 5/16 Four Holes Tapping } \\
\text { M14 }\end{array}$ & $\begin{array}{l}\text { Conv. Centre } \\
\text { Lathe }\end{array}$ & $10 \mathrm{~min}$ & $100 /-$ & 16.67 & -- & 2.67 \\
\hline 7 & Cleaning, Checking and Final Inspection & Manual & $5 \mathrm{~min}$ & nil & nil & 0.50 & 1.33 \\
\hline
\end{tabular}

\section{Collecting production and rejection data}

Data about production together with corresponding rejections i.e. defectives for the vital component viz. gearbox housing was collected on month to month production basis for the last one year, i.e., from March 2017 to August 2017 with prevailing process and from October 2017 to March 2018 using advanced method to review as well as analyze the defects arising out in producing the essential component. Table 2 shows production/rejection trend making use of the existing process.
The existing material, capital-labor-machine, and aggregate productivity calculated on the month to month production basis for gearbox housing is shown in table 3 , which is based on the under given information by the accounts department of the enterprise;

Selling Price per Component (Rs): 950.00

Material Cost per Component (Rs): 625.00

Manufacturing Cost per Component (Rs): 268.00

Table 2 Production/ rejection trend making use of existing process

\begin{tabular}{|c|c|c|c|}
\hline S. No. & Month of Year & Monthly Production & Monthly Defectives/ Rejections \\
\hline $\mathbf{1}$ & March 2017 & 770 & 34 \\
\hline $\mathbf{2}$ & April 2017 & 752 & 30 \\
\hline $\mathbf{3}$ & May 2017 & 820 & 36 \\
\hline $\mathbf{4}$ & June 2017 & 675 & 27 \\
\hline $\mathbf{5}$ & July 2017 & 755 & 31 \\
\hline $\mathbf{6}$ & August 2017 & 825 & 35 \\
\hline
\end{tabular}

Table 3 Existing materials, capital-labor-machine, and aggregate productivity

\begin{tabular}{|c|c|c|c|c|c|c|}
\hline Month & $\begin{array}{c}\text { Revenue from } \\
\text { Production (Rs) } \\
{[\mathrm{x}]}\end{array}$ & $\begin{array}{c}\text { Material Cost } \\
\text { (Rs) } \\
{[y]}\end{array}$ & $\begin{array}{c}\text { Capital, Labour and } \\
\text { Machining } \\
\text { Cost/Expenses(Rs) } \\
{[\mathrm{z}]}\end{array}$ & $\begin{array}{c}\text { Material } \\
\text { Productivity } \\
x / y\end{array}$ & \begin{tabular}{|c|} 
Capital, Labour, and \\
Machine \\
Productivity \\
x/z \\
\end{tabular} & $\begin{array}{c}\text { Aggregate } \\
\text { Productivity } \\
x / y+z\end{array}$ \\
\hline March, 2017 & 699200 & 481250 & 206360 & 1.452 & 3.388 & 1.0168 \\
\hline April, 2017 & 685900 & 470000 & 201536 & 1.459 & 3.403 & 1.0213 \\
\hline May, 2017 & 744800 & 512500 & 219760 & 1.453 & 3.389 & 1.0171 \\
\hline June, 2017 & 615600 & 421875 & 180900 & 1.459 & 3.402 & 1.0212 \\
\hline July, 2017 & 687800 & 471875 & 202340 & 1.457 & 3.399 & 1.0201 \\
\hline Aug, 2017 & 750500 & 515625 & 221100 & 1.455 & 3.394 & 1.0186 \\
\hline
\end{tabular}

Table 4 Operation time chart for gearbox housing using improved methods

\begin{tabular}{|c|c|c|c|c|c|c|c|}
\hline $\begin{array}{l}\dot{0} \\
\dot{0}\end{array}$ & Operations description & $\begin{array}{c}\text { Connected } \\
\text { Machine }\end{array}$ & $\begin{array}{c}\text { Avg. Cycle } \\
\text { Time }\end{array}$ & $\begin{array}{l}\text { Machining } \\
\text { Rate/ } \\
\text { Hour }\end{array}$ & $\begin{array}{c}\text { Component } \\
\text { Cost }\end{array}$ & $\begin{array}{l}\text { Material } \\
\text { shipping } \\
\text { Cost }\end{array}$ & Helper Cost \\
\hline 1 & Rough and Finish Machining Bore $\emptyset 141$ & $\begin{array}{l}\text { Centre } \\
\text { Lathe }\end{array}$ & $15 \mathrm{~min}$ & $80 /-$ & 20.00 & 1.00 & 4.00 \\
\hline 2 & $\begin{array}{c}\text { Finish Machine Bore } \emptyset 72 \mathrm{H}^{8} \text { and Bore } \varnothing 90 \mathrm{H}^{8} \\
\text { Finish Groove Dia. } \emptyset 75 \text { and } \varnothing 95.5 \text {, Central } \\
\text { Dia.70 }{ }^{ \pm 0.2} \text { Bore To Bore Finish }\end{array}$ & HMC & $20 \mathrm{~min}$ & $400 /-$ & 133.33 & 0.50 & 4.00 \\
\hline 3 & $\begin{array}{l}\text { Top Dimension } 190 \text { Finish Drill Ø12 Four } \\
\text { Holes }\end{array}$ & VMC-500 & $10 \mathrm{~min}$ & $300 /-$ & 50.00 & -- & 2.67 \\
\hline 4 & \begin{tabular}{|c|} 
Opening Of Drilled Hole Ø8.5 Eight Holes, \\
Tapping M10 Four Holes, Drill Ø6.8 One Hole, \\
Tapping 5/16 Four Holes Tapping M14 \\
\end{tabular} & $\begin{array}{c}\text { R-Drill } \\
\text { Conventional }\end{array}$ & $10 \mathrm{~min}$ & $100 /-$ & 16.67 & 1.00 & 1.33 \\
\hline 5 & Cleaning, Checking and Final Inspection & Manual & $5 \min$ & NIL & 5.00 & -- & 2.5 \\
\hline
\end{tabular}




\section{Validating the Proposed Process}

Table 4 shows operation time chart for gearbox housing using improved methods implementing clustering concept.

Subsequently, Table 5 shows production/rejection trend for 6 months i.e. Oct 2017 to Mar 2018, making use of the improved process.

Table 5 Production/ rejection trend making use of improved process

\begin{tabular}{|c|c|c|c|}
\hline S. No. & $\begin{array}{c}\text { Month of } \\
\text { Year }\end{array}$ & $\begin{array}{c}\text { Monthly } \\
\text { Production }\end{array}$ & $\begin{array}{c}\text { Monthly } \\
\text { Defectives/ } \\
\text { Rejections }\end{array}$ \\
\hline $\mathbf{1}$ & Oct 2017 & 924 & 20 \\
\hline $\mathbf{2}$ & Nov 2017 & 912 & 18 \\
\hline $\mathbf{3}$ & Dec 2017 & 984 & 21 \\
\hline $\mathbf{4}$ & Jan 2018 & 820 & 17 \\
\hline $\mathbf{5}$ & Feb 2018 & 906 & 18 \\
\hline $\mathbf{6}$ & Mar 2018 & 990 & 22 \\
\hline
\end{tabular}

Improvement of productivity using the proposed method
Making use of the developed universal fixture for the manufacture of the component as mentioned earlier viz. gearbox housing has reduced the related machines from six to four due to clustering. In spite of the user better hourly price system, the component producing cost has considerably decreased as compared with previous manufacturing cost due to much less machining and helper cost attributable to reduced cycle time. Operation number $2 \& 3$ shown in table 1 , are performed in a single setting on $\mathrm{HMC}$, while operation number $5 \& 6$ performed on Radial drilling machine in a unique setting. Manufacturing cycle time of the vital component has decreased extraordinarily inflicting proportionate boom in month-to-month production and therefore in month-to-month productiveness. The monthly material, capital-labormachine and aggregate productivity using improved method calculated on following reduced manufacturing cost basis are shown in Table 6 .

Selling Price per Component (Rs): 950.00

Material Cost per Component (Rs): 625.00

Manufacturing Cost per Component (Rs): 242.00

Table 6 Improved materials, capital-labor-machine, and aggregate productivity

\begin{tabular}{|c|c|c|c|c|c|c|}
\hline Month & $\begin{array}{c}\text { Revenue generated } \\
\text { from Production } \\
\text { (Rs) } \\
\mathbf{( x )}\end{array}$ & $\begin{array}{c}\text { Material Cost } \\
\text { (Rs) (y) }\end{array}$ & $\begin{array}{c}\text { Capital, Labour and } \\
\text { Machining } \\
\text { Cost/Expenses(Rs) } \\
\mathbf{( z )}\end{array}$ & $\begin{array}{c}\text { Material } \\
\text { Productivity } \\
\mathbf{x} / \mathbf{y}\end{array}$ & $\begin{array}{c}\text { Capital, Labour, } \\
\text { and Machine } \\
\text { Productivity } \\
\mathbf{x} / \mathbf{z}\end{array}$ & $\begin{array}{c}\text { Aggregate } \\
\text { Productivity } \\
\mathbf{x} / \mathbf{( y + z )}\end{array}$ \\
\hline Oct, 2017 & 858800 & 577500 & 223608 & 1.487 & 3.840 \\
\hline Nov, 2017 & 849300 & 570000 & 220704 & 1.490 & 3.848 \\
\hline Dec, , 2017 & 914850 & 615000 & 238128 & 1.488 & 3.841 \\
\hline Jan, 2018 & 762850 & 512500 & 198440 & 1.488 & 3.844 \\
\hline Feb, 2018 & 843600 & 566250 & 219252 & 1.489 & 1.0741 \\
\hline Mar, 2018 & 919600 & 618750 & 239580 & 1.486 & 1.0723 \\
\hline
\end{tabular}

\section{Results and discussion}

After using the advanced manufacturing system, the enterprise inspects every tenth part somewhat of every fifth issue, due to extreme accuracy and finish performed on HMC, therefore lowering the inspection cost appreciably. HMC takes 20 minutes time to complete the clustered operations. The cycle time of the principal component viz. gearbox housing now comes out to be 60 minutes using the progressed procedure which is exhibited in Table 5, earlier the said time was 75 minutes using the present method as shown in Table 1.

With the use of improved tooling on HMC, a perfect finish with precise tolerances is comfortably achievable and is closer than the prevailing tolerance limit, hence resulting in reduced rejection rate. Use of carbide tooling on CNC system, in preference to the use of HSS tools on traditional machines, has ended in extra than $10 \%$ reduction in the tooling cost. The stated carbide tools resist better temperature and retain their sharp edges for comparatively long duration due to the extreme red hardness and toughness property, therefore ensuring longer tool life. Feed and rotational speeds have additionally accelerated fantastically for accomplishing the identical operation.
Analyzing the existing and improved methods statistically

The chart used for monthly fraction defectives with variable sample size is P-Chart. The straight horizontal axis with ordinate value 0.0420 is the center line, remarked as CL on the control chart shown in Figure 2.

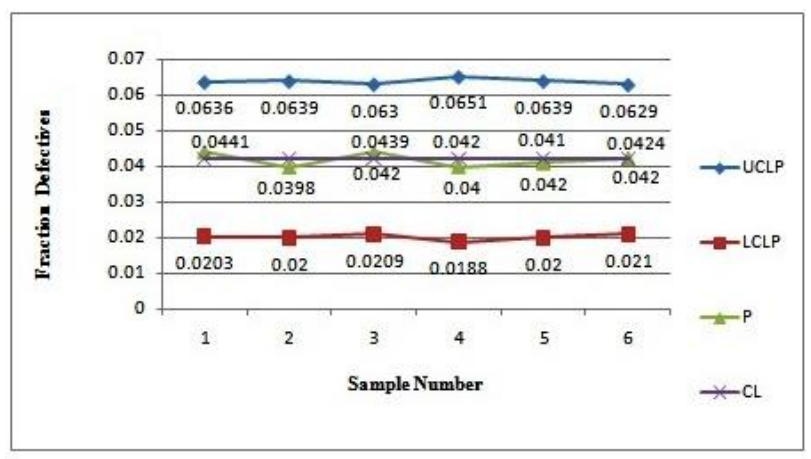

Fig 2 Control chart for existing method

It's far inferred that triangular points for $1^{\text {st }}, 2$ ndand $4^{\text {th }}$ fraction defective for the corresponding samples is relatively more distant from the centerline, which renders increased rejection rate. On interpreting the graphs for existing and progressed procedure it's miles 
apparent that the triangular points for the above-said samples are falling closer to the centerline, CL with ordinate value 0.0209 , in Figure 3, using the advanced method. Hence improved process is better statistically managed. Inference of existing and progressed chart analyzed that month-to-month variation in fraction defectives has reduced with advanced method.

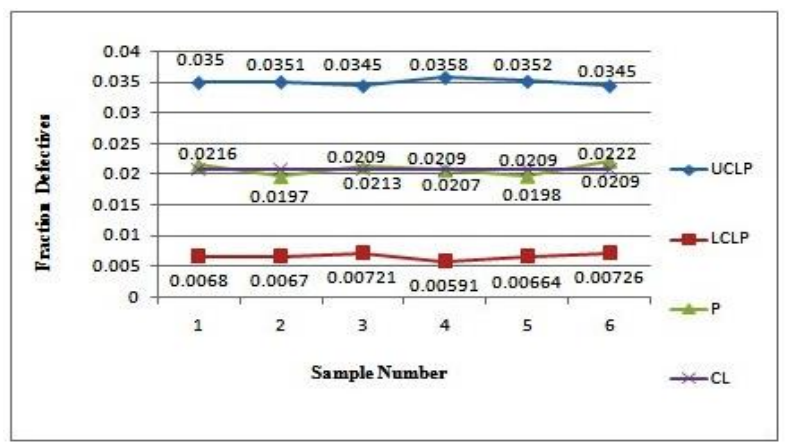

Fig 3 Control chart for improved method

\section{Conclusions}

From the interpretation of existing and proposed charts, it was concluded that the advanced procedure is under better statistical control. Since the number of machines required for performing the necessary operations has reduced to four of six, the probability of error got minimized due to a fantastic rigidity of the machine. A reduction of $9.7 \%$ in part manufacturing cost was claimed due to decreased cycle time even after using higher hourly rate of machines. Tooling cost curtailed by more than $10 \%$ because of additionally long life of carbide tools utilized on CNC machine. After enforcing clustering concept, close dimensional tolerance becomes possible on manufactured parts. Monthly production has increased by $20 \%$, corresponding to a reduction in cycle time; resultantly rejection was curbed up to $2 \%$. A justified saving of 15 minutes in cycle time was recorded due to clustering. As a consequence average material productivity has enhanced by $2.26 \%$, while capital, machine, and labor productivity has advanced by $13.20 \%$.Resultantly average total productivity has stepped up by $5.25 \%$.

\section{References}

Arditi, D., \&Mochtar, K. (2000) Trends in productivity improvement in the US construction industry. Construction Management \& Economics, Vol18 (1), pp. 15-27.

Aw, B. Y., Chen, X., \& Roberts, M. J. (2001) Firm-level evidence on productivity differentials and turnover in Taiwanese manufacturing. Journal of Development Economics, Vol66 (1), pp.51-86.

Balk, B. M. (2005, December). Annual and quarterly productivity measures. In Economic Measurement Group Workshop sponsored by the Center for Applied Economic Research at the University of New South Wales, the Australian Bureau of Statistics and the Australian Research Council, held at Coogee, Australia, Vol1.

Bond, J. T., Galinsky, E. (2006). How Can Employers Increase the Productivity \& Retention of Entry-Level, Hourly Employees, Research Brief, Vol 2.
Bryson, L. S., Maynard, C., Castro-Lacouture, D., Williams, R. L. (2005).Fully autonomous robot for the paving operations. In Proceedings of 2005 ASCE Construction Research Congress, pp. 5-7.

Card, D.N. (2006)The challenge of productivity measurement Proceedings of Pacific Northwest Software Quality Conference, pp.1-10.

Carrington R, O'Donnell C, Rao DP (2016). Australian university productivity growth and public funding visited. Studies in Higher Education, pp.1-22.

Dash, M., Kabra, G., Singh, A. (2010). Productivity Growth of Mfg Sector in India an Inter-State Analysis. European Journal of Scientific Research, Vol44(3), pp.387-399

Doo, M., Sohn, S. (2008).Productivity improvement of $\mathrm{mfg}$ SMEs via technology innovation in Korea. In 7th WSEAS Int. Conference on Artificial Intelligence, Knowledge Engineering and Data Bases (AIKED'08), pp. 20-22.

Faulk, S., Gustafson, J., Johnson, P. M., Porter, A. A., Tichy, W.,Votta, L. (2004). Toward accurate HPC productivity measurement.In Proceedings of the First Int. Workshop on Software Engg for High-Performance Computing System Applications.

Fernandes (2008), "Firm Productivity in Bangladesh Manufacturing Industries", Development Research Group, the World Bank, pp.1-36.

Goldar, B. (2004). Productivity trends in Indian manufacturing in the pre-and post-reform periods. Indian Council for Research on Int. Economic Relations.

Görg, H.,Hanley, A. (2005). International outsourcing and productivity: evidence from the Irish electronics industry. The North American Journal of Economics \& Finance, Vol16 (2), pp. 255-269.

Gunasekaran, A., Cecille, P. (1998) Implementation of productivity improvement strategies in a small company. Technovation, Vol18(5), pp.311-320.

Gupta, A. (2010). Indian manufacturing productivity: What caused the growth stagnation before the 1990s? International Productivity Monitor, Vol20, pp.85-102.

Hemanand, K., Amuthuselvan, D. (2012). Improving Productivity of Manufacturing Division using Lean Concepts and Development of Material Gravity Feeder-a case study. International Journal of lean thinking, Vol3(2), pp.117-134.

Hsieh, C. T., Klenow, P. J. (2007). Misallocation and manufacturing TFP in China and India National Bureau of Economic Research.(No. w13290).

Kathuria, V., Raj, R., Sen, K. (2010).State business relations and manufacturing productivity growth in India.Available at SSRN 1544290

Lieberman, M. B., Demeester, L. (2002). Inventory reduction and productivity growth: evidence from the Japanese automotive sector.

Medda, G., Piga, C. A. (2014). Technological spillovers and productivity in Italian manufacturing firms. Journal of productivity analysis, Vol41(3), pp.419-434.

Mohaddes, S. A.,Mazhari, M. (2008). Total and Input Factor Productivity Analysis of Poultry Production in Khorasan Province, Iran.American-Eurasian Journal Agricultural and Environmental Science, Vol2, pp.151-4.

Motohashi, K., Yuan, Y. (2009). IT, R\&D and productivity of Chinese manufacturing firms.

In RIETI Working Papers, 09-E-007.Research Institute of Economy, Trade \& Industry Tokyo.

Natarajan, R. R. S., Duraisamy, M. (2008). Efficiency and productivity in the Indian unorganized Mfg sector: did reforms matter?. International Review of Economics, Vol55(4), pp.373. 
Nataraj, S. (2011). The impact of trade liberalization on productivity: Evidence from India's formal and informal mfg sectors. Journal of International Economics, Vol85(2), pp.292-301.

Saleeshya, P. G.,Bhadran, A. (2015). Productivity improvement through lean initiative in surgical equipment Mfg. Company: a case study. International Journal of Business \& Systems Research, Vol9 (4), pp.297-314.

Sheth, J. N.,Sisodia, R. S. (2002). Marketing productivity: issues and analysis. Journal of Business Research, Vol55(5), pp.349-362.

Singh, S., Singhal, S. (2018). Productivity perfection and analysis in manufacturing top cover: implementing clustering approach with combination tooling. Journal of Engineering Technology, Vol.6, Special Issue (Emerging Trends in Engineering Technology), pp. 339-353.

Sivakumar, A. Saravanan, K. (2011). A simulation-based analysis for productivity improvement in sick chemical dyeing factory: a research article. Int. Journal of Electronic Transport, Vol1(1), pp. 96-110.

Skorupinska, A.,Torrent-Sellens, J. (2017). ICT, Innovation and Productivity: Evidence Based on Eastern European Manufacturing Companies. Journal of the Knowledge Economy, Vol8(2), pp.768-788.

Sohail, S. M. (2006). Analysis of Productivity Measures and the Factors Affecting Accurate Measurement of Productivity.

Trimble, R., Copeland, K., MacIntyre, J.,Smith, P. (2013). The use and impact of mfg productivity improvement tools \& methodologies within the automotive component industry.Engineering Management Research, Vol2 (1).

Walia, R. S., Shan, H. S.,Kumar, P. (2009). Enhancing AFM process productivity through improved fixturing. The International Journal of Advanced Mfg. Technology, Vol44(7), pp.700-709.

Yazid H.B. (2007), "Productivity Improvement Using One Piece Flow Technique", University Technical Malaysia Melaka, p.p. 1-26. 